P-ISSN: 2774-4574; E-ISSN: 2774-4582

TRILOGI, 2(3), September-Desember 2021 (348-354) @2021 Lembaga Penerbitan, Penelitian, dan Pengabdian kepada Masyarakat (LP3M) Universitas Nurul Jadid Paiton Probolinggo

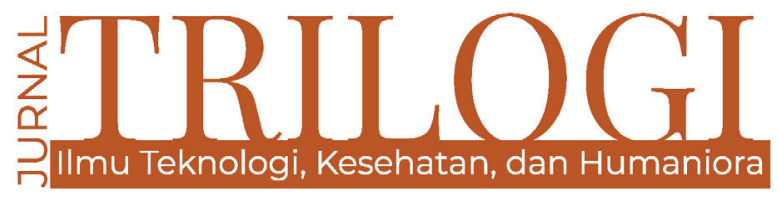

\title{
EFEKTIVITAS PEMBELAJARAN MENGGUNAKAN MEDIA SOSIAL SELAMA PANDEMI COVID-19 DI PERGURUAN TINGGI
}

\section{Faizin Faizin}

Universitas Nurul Jadid, Probolinggo, Indonesia

hfaizin1967@gmail.com

\author{
Atikul Ansori \\ Universitas Nurul Jadid, Probolinggo, Indonesia \\ Muhammad Fathul Amin \\ Universitas Nurul Jadid, Probolinggo, Indonesia
}

\begin{abstract}
Abstrak
Penelitian ini menjelaskan secara faktual tentang pembelajaran menggunakan media online selama kuliah jarak jauh selama epidemi Covid 19. Beberapa siswa digunakan sebagai sumber informasi dengan menggunakan metode kualitatif dan teori behaviorisme serta kognitif. Pembelajaran Online Jarak Jauh dapat memanfaatkan sosial media pembelajaran online virtual melalui video conference, telekonferensi, secara berkelompok di media sosial. Media sosial adalah strategi untuk menghilangkan kebosanan atau stres dari belajar di rumah. Inimerupakan kondisi baru bagi dosen dan mahasiswa, maka peran dosen sangat dibutuhkan dalam mengelola atau mengelola pembelajaranmulai dari perencanaan, pengorganisasian, penggerakan dan evaluasi dalam rangka meningkatkan efektivitas belajar mengajar selama pandemi COVID-19.
\end{abstract}

Kata kunci: pembelajaran; media sosial; covid-19

\begin{abstract}
This study explains factually about learning to use online media during distance lectures during the Covid 19 epidemic. Some students are used as sources of information by using a qualitative approach. By using behaviorism and cognitive theory. Online Distance Learning can take advantage of virtual online learning social media through video conferencing, teleconferencing, in groups on social media. Social media is his way out to relieve boredom or stress from studying at home. This is a new condition for lecturers and students, so the role of lecturers is very much needed in managing or managing learning starting from planning, organizing, mobilizing and evaluating in order to increase the effectiveness of teaching and learning processes during the COVID-19 pandemic.
\end{abstract}

Keywords: learning; social media; covid 19 


\section{Pendahuluan}

Pendidikan merupakan salah satu cara untuk menghasilkan Sumber Daya Manusia (SDM) yang berkualitas dengan pengalamanperubahan pengetahuan, keterampilan dan sikap. Perubahan ini bisa menjadi modal untuk memperbaiki kompetensi diri dalam menghadapi era globalisasi yang selalu mengalami perubahan (Sitorusdkk, 2019). Mulai awal tahun 2020, dunia dihebohkan dengan wabah tersebutdari virus Corona (COVID-19) yang telah menginfeksi hampir semua negara di dunia.Sejak Januari 2020, WHO telah menyatakan dunia memasuki keadaan darurat global terkaitterhadap virus ini. Virus corona yang menyerang sistem pernapasan telah mencatat lebih dari28 juta kasus dari 213 negara terinfeksi di dunia. Dikutip Pikiran-Rakyat.com dari halaman Worldo Meters, per Minggu, 13 September 2020, jumlah total menjadiTepatnya telah mencapai 28.916.010 kasus positif COVID-19 secara global. Epidemi globaltelah melanda dunia, seperti yang terjadi di Indonesia, sehingga program stay at home adalahdilaksanakan sebagai upaya menekan penyebaran Covid-19 (Zahrotunni'mah, 2020: 248). Untuk memenuhi program pemerintah, model pembelajaran dialihkan ke virtualruang kelas, sehingga siswa tetap mendapatkan haknya untuk menimba ilmu namun tetap aman di rumah.Buana (2020) menjelaskan langkahlangkah yang telah dilakukan pemerintah untuk dapat mengatasikasus luar biasa ini, salah satunya dengan menyosialisasikan gerakan social distancing.

Surat Edaran Nomor 4 Tahun 2020 tentang Pelaksanaan Kebijakan Pendidikan dimasa darurat penyebaran Corona Virus Disease (Covid-19) pembelajaranproses dari rumah dilakukan dengan ketentuan sebagai berikut: Belajar dari rumah melalui pembelajaran online/jarak jauh dilakukan untuk memberikan pengalaman belajar yang bermaknabagi siswa, tanpa dibebani tuntutan untuk menyelesaikan semua kurikulumprestasi untuk kenaikan kelas dan kelulusan. Belajar dari rumah bisa fokuspendidikan kecakapan hidup antara lain terkait pandemi ini, Arizona (2020: 66). Sedang belajardari rumah kegiatan dan tugas dapat bervariasi antara siswa, sesuai dengan kepentingan dan kondisi masing-masing, termasuk mempertimbangkan akses/fasilitas belajar dirumah. Bukti atau produk kegiatan belajar dari rumah diberikan secara kualitatif danumpan balik yang berguna dari dosen, tanpa diharuskan memberikan skor kuantitatif.Banyak manfaat yang didapat saat belajar online/jarak jauh di masa pandemi ini, salah satunyayaitu kita bisa belajar kapan saja dan dimana saja yang akan memberikan kenyamanan bagi merekakami yang sedang belajar online/jarak jauh.

Dalam rangka meningkatkan kewaspadaan dan pencegahan penularan virus corona dikampus. Dosen juga memiliki tugas, misalnya menyiapkan bahan ajar untuk diunggah ke siswa, menentukan media pembelajaran seperti grup Whatsapp, Email,Google Classroom, atau aplikasi media pembelajaran lainnya sesuai rekomendasi Kementerian Agama dan Kementerian Pendidikan dan Kebudayaan. Orang tua jugadiminta untuk memastikan siswa melaksanakan kegiatan belajar di rumah masing-masing, batasiizin kegiatan di luar rumah, koordinasi dengan dosen atau kampus, bantuansiswa menerapkan pola hidup bersih dan sehat (PHBS) di rumah dan sebagainya. Siswa adalahdiminta untuk mempelajari materi atau materi pelajaran yang diunggah oleh dosen melalui media yang disepakati.

Cukup banyak pilihan aplikasi pembelajaran online yang bisa diterapkan didunia pendidikan. Salah satu aplikasi gratis dan familiar yang diimplementasikan adalahAplikasi Google Kelas. Guru, dosen, tutor dan instruktur pada umumnya dapatmembuka kelas dan mengundang siswa ke kelas. Pembelajaran online dalam aplikasi dapat mengambiltempat dengan berbagai materi dan tugas yang diberikan guru kepada siswa. Guru bisajuga memberikan nilai terkait tugas yang dikumpulkan dengan rapi dan terarsip dengan baik. Itupembelajaran online yang diterapkan memungkinkan guru dan siswa untuk melaksanakan pembelajaran tanpamelalui tatap muka di kelas dengan memberikan materi pembelajaran (berupaslide power point, e-book, video pembelajaran dll, tugas (independen atau kelompok), sebagaiserta penilaian. (Silalahi dkk, 2020)

Namun, beban orang tua saat ini sangat berat. Penyesuaian yang cukup berat akan sebenarnya terjadi di rumah, terutama orang tua dalam mendampingi dan mengawasi anak ketika mereka berpartisipasi dalam proses belajar di rumah dengan memberikan pemahaman bahwa mereka harustetap belajar seperti biasa. Penulisan artikel ini bertujuan untuk memberikan tinjauan pustaka yang akanfokus pada konsep pembelajaran jarak jauh melalui metode kampus online danperan penting pengawasan orang tua dalam mengimplementasikan kampus online di masa pandemi Covid-19 pandemi. Kondisi ini 
menuntut lembaga pendidikan untuk berinovasi dalam pembelajaranproses. Salah satu bentuk inovasi adalah dengan pembelajaran online atau online (Jamaluddin, D., Ratnasih,T., Gunawan, H., \& Paujiah, E. (2020).

Namun dalam pembelajaran online hal tersebut tidak terlepas dari permasalahan yang menjadikendala dalam pelaksanaannya, termasuk pembelajaran online bagi siswa di lembaga pendidikaninstitusi di pendidikan tinggi. Oleh karena itu, diperlukan berbagai solusi sebagai solusi sebagaiserta langkah-langkah yang akan diambil ke depan sebagai proyeksi. Hambatan, solusi dan proyeksi daripembelajaran online bagi calon dosen penting untuk diketahui, mengingat hal inisistem pembelajaran yang digunakan oleh dosen sebagai lembaga yang menghasilkan calon tenaga kerja, sebagaiakibat dari peristiwa luar biasa yaitu wabah Covid-19.

\section{Metode}

Teori behavioristik adalah teori yang membahas tentang perubahan perilaku seseorang berdasarkanpada pengalaman baru. Teori behavioristik menekankan pada pembentukan perilaku yang dapatterlihat dari hasil proses pembelajaran selama pandemi COVID-19. jugadalam penelitian ini menggunakan teori kognitif yaitu perilaku individu dapat diarahkan melaluisituasi baru, seperti belajar dengan model online. Bersamaan dengan memiliki hubungannya dengan tujuan arak-arakan. Karena, dalam sifat dinamis siswaperilaku itu mempengaruhi efektifitas proses belajar mengajar.

Penelitian ini dilakukan dengan menggunakan metode deskriptif dengan pendekatan kualitatif dan studi literatur. Penelitian kualitatif digunakan dengan mengacu pada pendapat Sugiyono,2009: 2), bahwa metode penelitian kualitatif merupakan metode penelitian naturalistik karenapenelitian dilakukan dalam kondisi alami (natural setting), dan data yang dikumpulkan adalahdianalisis secara kualitatif. (Miles, MB, \& Huberman, M., 1994). Instrumen penelitianterdiri dari panduan wawancara yang dilakukan melalui telepon dan media online melaluiaplikasi WhatsApp. Penelitian ini dilakukan pada tahun 2020. Metode penelitian yang kamiyang dilakukan adalah metode penelitian kualitatif. Pendekatan atau penelusuran untuk mengeksplorasi danmemahami fenomena sentral. Teknik pengumpulan data yang kami lakukan adalah menggunakan googlemembentuk. Kami juga menggunakan google form ini karena lebih cepat dan lebih luas untuk pendistribusiannyakuisioner kepada siswa. Di sisi lain, karena kebijakan jarak sosial ini,tidak mungkin jika kita menggunakan metode wawancara langsung.

\section{Hasil dan Pembahasan}

Dalam interaksi belajar sangat dipengaruhi oleh beberapa komponen, yaitu:mahasiswa, dosen, pimpinan kampus, kurikulum, fasilitas kampus (perpustakaan), dan lain-lainfasilitas lain yang diperlukan dalam proses pembelajaran sehingga menunjang kualitaspembelajaran1 Dengan demikian, kegiatan pembelajaran dapat membawa perubahan bagi peserta didik, baik perubahandalam pengetahuan, perilaku, dan keterampilan. Dengan adanya perubahan tersebut tentunya siswa akan terlatihdalam memecahkan masalah kehidupan dan dapat beradaptasi dengan lingkungannya. Ada 2 (dua) pendekatanhingga Pembelajaran Jarak Jauh (PJJ) yang meliputi pembelajaran jarak jauh online dan pembelajaran offline.

Manajemen pembelajaran memiliki kedudukan yang sangat penting dalam rangka meningkatkan efektivitas proses belajar mengajar, terutama pada masa daruratpenyebaran Corona Virus Disease-19 (COVID-19) seperti yang kita alami saat ini. Bermacam-macamupaya yang dilakukan untuk meningkatkan kualitas pendidikan dengan tetap mempertimbangkan kesehatan protokoler sesuai dengan Keputusan Menteri 4. Berbagai kendala, kesulitan, dan keterbatasan yang dihadapi dalam proses belajar mengajar, mulai dari faktor siswa,keluarga siswa, serta sarana dan prasarana yang kurang representatif. Adaketerbatasan faktor pelajar dengan alasan paket internet habis. Orang tua banyak mengeluh karena harus membeli paket dengan memasang indihome dirumah (Wawancara dengan siswa dan orang tua).

Pemanfaatan teknologi informasi ini dapat berperan sebagai media yang menyediakan antaramahasiswa dan dosen, sumber belajar dan sarana untuk evaluasi pembelajaran yang efisien. Saat melakukan wawancara dengan siswa, dengan pembelajaran online, siswa mendapatkaninformasi terbaru dengan mengakses aplikasi zoom untuk dapat bertemu langsung denganrekan-rekan dari daerah masing-masing (wawancara dengan mahasiswa di beberapa universitas). Menurut Bell et al., (2017) pembelajaran online memungkinkan interaksi melalui web meskipunmereka berada 
di tempat yang jauh dan berbeda (Arzayeva, dkk., 2015). Keuntungan menggunakan online belajar adalah bahwa belajar itu mandiri dan interaktivitas tinggi, dapat meningkatkan tingkat memori,memberikan pengalaman belajar yang lebih, dengan teks, audio, video dan animasi. (Oknisih, N., \&Suyoto, S., 2019). Semuanya digunakan untuk menyampaikan informasi, dan juga memudahkan untukmenyampaikan, memperbarui konten, mengunduh, siswa juga dapat mengirim email ke siswa lain, mempostingberkomentar di forum diskusi, menggunakan ruang obrolan, hingga tautan konferensi video untuk berkomunikasisecara langsung. Model pembelajaran online menjadi pilihan pertama yaitu sebanyak $100 \%$ dosen menggunakan fasilitas WA atau yang sering disebut dengan WhatsApp, dimana dosen berkreasiGrup WhatsApp sehingga semua siswa dapat terlibat dalam grup. Tugas diberikan melalui WhatsApp. Kalaupun mahasiswa masih kurang paham, dosen juga akan menambahkan dengan mengirimkanvideo atau melakukan Panggilan Video WhatsApp dengan siswa. (Kim, Wang, \& Oh, 2016).

Pemberian tugas memudahkan siswa melalui pesan WhatsApp.Tugas juga dapat dikirim melalui WhatsApp dan biasanya siswa mengambil fototugas dan mengirimkannya ke dosen. Banyak video tutorial yang dibuat oleh dosenjuga telah diunggah melalui WhatsApps. Cara siswa mengerjakan tugas adalah dengan mengerjakantugas secara manual dengan menulis di buku kemudian foto hasil tugas tersebutdikirim melalui chat WhatsApp. Dalam upaya memperkuat penilaian, dosen juga menambahkantugas dalam bentuk Google Form. Penggunaan WhatsApp digunakan oleh dosen sebagaiberarti mengumpulkan tugas. Alasan dosen memilih menggunakan WA adalahlebih praktis, lebih mudah dipahami anak, lebih efektif karena tidak memerlukanbanyak kuota dalam proses pembelajaran. Alasan lain adalah lebih mudah dan semua orang tuawali siswa dapat menggunakannya dan itu bukan hal yang asing. Saat ini WA lebih mudah dan bisadijangkau oleh banyak kelompok. Keuntungan menggunakan WA adalah lebih mudah dioperasikan danlebih mudah dalam mengirimkan soal dan materi. Bahkan jika Anda ingin mengadakan pertemuan virtual, dosen bisa langsung menggunakan fitur WA Video Call. WA sederhana, efektif dan efisiendalam penggunaannya.
Kegiatan pembelajaran online berjalan dengan baik dan menyenangkan walaupun ada kendala dalam penggunaanaplikasi Zoom yaitu situasi dan kondisi lingkungan rumah ataujaringan (sinyal), dapat menghambat siswa dengan koneksi internet yang lambat, tetapi jika adainformasi yang kurang jelas dosen akan mengulang penjelasannya sampai mahasiswa mengertimateri yang diberikan oleh dosen. Untuk Google Classroom, saya menggunakannya untuk berbagi informasiterkait dengan mata kuliah saya dan untuk Zoom saya gunakan untuk diskusi dan absensi mahasiswa.

Pembelajaran online adalah pembelajaran yang dilakukan dengan menggunakan koneksi internet sebagai penghubunguntuk komunikasi antara pendidik dan siswa tanpa kontak fisik. Pembelajaran online memiliki beberapa kelemahan yaitu penggunaan jaringan internet memerlukan infrastruktur, membutuhkan banyak uang, komunikasi melalui internet memiliki berbagai hambatan / lag. Selain itu, ada juga kelebihan yang meliputi tingkatinteraksi antara mahasiswa dan dosen, pembelajaran dapat dilakukan dimana saja dan kapan saja(fleksibilitas waktu dan tempat), Menjangkau siswa dalam lingkup yang luas (berpotensi menjangkau dunia global). audiens), dan membuatnya lebih mudah untuk perbaikan. dan penyimpanan bahan pembelajaran (mudahmemperbarui konten serta kemampuan yang dapat diarsipkan.

Kesulitan muncul tidak hanya dalam hal keterampilan dalam menggunakan teknologi, tetapi juga terkait denganbeban kerja yang besar mengingat banyaknya mata kuliah yang harus dihadapi di erapandemi COVID-19. Hal ini terjadi karena siswa terbiasa dengan rutinitas tatap muka.pembelajaran tatap muka, sedangkan pembelajaran jarak jauh sebelumnya hanya dilakukan secara insidental. Sehingga perubahan pola belajar ini menghadirkan permasalahan tersendiri bagi siswa. munculnyatekanan dan stres pada siswa yang melakukan pembelajaran jarak jauh. Pada titik ini, tekanannya pasti terasa lebih berat, sehingga siswa banyak melakukan coping stress, salah satunya dengan melakukanpenggunaan media sosial. Jadi pada titik ini, media sosial harus menjadi jalan keluar untuk menyingkirkankebosanan atau stres karena belajar di rumah. Hanya saja hal-hal yang berbeda selamaPandemi covid19. Informasi yang berlebihan telah terbukti menyebabkan kelelahan media sosialdengan membebani kognisi individu. 
Pada tingkat pelaksanaan PJJ, satuan pendidikan dipersilakan untuk melamar (online atau offline atau konvergensi keduanya) berdasarkan kesiapan dan kemampuan pendidikan institusi. Sarana dan prasarana Pembelajaran Jarak Jauh Online dapat memanfaatkan gadget danlaptop melalui beberapa portal dan aplikasi pembelajaran online. Pembelajaran daringproses terdiri dari: pertama; Tatap muka virtual melalui konferensi video, telekonferensi, dan/ atau diskusi grup di media sosial atau aplikasi perpesanan. Dalam hal ini, pendidik dan siswa dapat berinteraksi secara langsung. Kedua; Sistem Manajemen Pembelajaran (LMS). LMS adalah sistem manajemen pembelajaran terintegrasi online melalui aplikasi.

Kegiatan pembelajaran di LMS meliputi pendaftaran dan pengelolaan akun,penguasaan materi, penyelesaian tugas, pemantauan hasil belajar,terlibat dalam forum diskusi, konsultasi dan ujian/penilaian. Contoh dari LMS termasuk kelas rumah pembelajaran virtual, kelas google, edmodo, moodle, zeniusruang dosen, guru seamolec LMS, dan sebagainya. Sementara itu, Pembelajaran Offline dapat menggunakanbuku, modul dan bahan ajar di lingkungan sekitar lembaga dan sebagainya.Waktu belajar online dan offline sepanjang hari menyesuaikan dengan ketersediaan waktu,kondisi, dan Pendidik melakukan kontrol atas program yang mereka buat sendiri,apakah sesuai dengan apa yang mereka tetapkan.

Pengawasan meliputi pengawasan, dan penilaian terhadap penerapan standar dan mendukung tercapainya tujuan pembelajaran. Jika ada kesalahan atau ada programyang tidak memenuhi target, segera direvisi dalam rencana, sehinggatujuan yang telah ditentukan dapat tercapai secara maksimal.Kegiatan pengawasan dilakukanoleh pendidik dalam rangka mencari informasi, menganalisis informasi, dan mengevaluasi data yang berkaitan dengan kegiatan belajar dan menggunakannya untuk mengontrol kegiatan belajar untuk mencapai tujuan belajar.Perbaikan dilakukan selama proses belajar mengajar dan juga dalamproses pembelajaran selanjutnya sebagai bagian dari kontrol pembelajaran yang diterapkan oleh pendidik. Selain memantau atau mengevaluasi program pembelajaran, pendidik juga melakukan pengawasan terhadap pencapaian kompetensi siswa. Pengawasan terhadap prestasi siswa kompetensi dilakukan dengan penyesuaian terhadap ketentuan kondisi darurat.
Proses ini berjalan pada skala yang belum pernah diukur dan diuji karena memilikitidak pernah terjadi sebelumnya. Tak pelak, desa terpencil dengan usia kampus yang sangat padat menjadibingung, karena infrastruktur teknologi informasi sangat terbatas. Muridpenilaian bergerak online dan ada banyak coba-coba dengan sistem yang tidak dapat diprediksi,nyatanya banyak penilaian yang dibatalkan. Yang kedua adalah dampak jangka panjang. Banyakkelompok masyarakat di Indonesia akan terkena dampak jangka panjang dari Covid-19. Itudampak jangka panjang pendidikan adalah aspek keadilan dan peningkatan ketimpangan antarakelompok masyarakat dan antar daerah di Indonesia.

Kondisi dosen di Indonesia belum sepenuhnya memahami penggunaanteknologi, hal ini terlihat dari dosen yang lahir pada tahun sebelum tahun 1980-an.Kendala teknologi informasi membatasi penggunaan media online. Begitu juga dengan siswayang kondisinya hampir sama dengan dosen, yang dimaksud dengan memahamipenggunaan teknologi. Perangkat dukungan teknis jelas mahal. Banyak di Indonesia yangdosen yang masih dalam kondisi ekonomi yang memprihatinkan. Kesejahteraan dosen dan mahasiswa telahmencegah mereka untuk sepenuhnya dibatasi dalam menikmati teknologi informasisarana dan prasarana yang sangat dibutuhkan oleh bencana Covid-19. Itujaringan internet masih belum merata di seluruh pelosok tanah air. Tidak semua mendidikperguruan tinggi, baik sekolah dasar maupun menengah, dapat menikmati internet.

Biaya juga menjadi kendala karena aspek kesejahteraan dosen dan mahasiswa adalah masih jauh dari harapan. Ketika mereka menggunakan kuota internet untuk memenuhi media online merekakebutuhan, jelas bahwa mereka tidak mampu untuk membayar untuk itu. (Naserly, MK, 2020). Ada sebuah dilema penggunaan media online, ketika menteri pendidikan mendorongproduktivitas untuk maju, tetapi di sisi lain keterampilan dan kemampuan keuangandosen dan mahasiswa belum bergerak ke arah yang sama. Negara belum sepenuhnyahadir dalam memfasilitasi kebutuhan keuangan dimaksud. Pembelajaran online membutuhkan fasilitasiseperti smartphone atau laptop, namun ada beberapa siswa yang tidak memiliki smartphone atau laptop ditambah tidak adanya kuota internet untuk melaksanakan pembelajaran online menjadi masalah besar bagidosen dan mahasiswa. 
Selain itu, dengan pembelajaran online, dosen juga menjadi kewalahan dalam melamar metode apa yang akan disampaikan dalam pembelajaran online agar siswa memahami materi? disajikan karena pembelajaran online dilakukan tidak tatap muka. Pembelajaran online tidakefektif karena ada alasan siswa yang tidak memiliki jaringan, tidak ada perangkat seperti handphone atau laptop. Oleh karena itu, dosen mengalami kesulitan dalam melaksanakan hal tersebutproses belajar daring. Setiap siswa sangat ingin belajar dengan tenang dan mudahdipahami dalam proses pembelajaran online. Namun, dosen juga menjadi bingung tentangbagaimana pembelajaran online dapat dilakukan tanpa hambatan dan tidak menjadibeban bagi siswa.

Ada kendala bagi dosen dalam melakukan pembelajaran online kepada mahasiswa, diantaranyakurangnya pemahaman siswa saat melaksanakan proses pembelajaran online. Inikarena mahasiswa tidak memahami pembelajaran yang diajarkan oleh dosen karena tidakbertatap muka dan dosen kesulitan memantau kemajuan belajar mahasiswa. Itufaktor utama yang lebih penting lagi adalah minimnya fasilitas yang dimiliki siswa ketikabelajar online karena tidak semua siswa memiliki komputer atau smartphone sebagai media pembelajaranmenggunakan online. Selain itu, faktor lainnya adalah paket internet yang tidak bisadijangkau oleh semua siswa.

\section{Kesimpulan}

Masa pandemi Covid-19 mungkin berbeda karena kebiasaan mengajardosen selalu tatap muka di kelas, sekarang dosen mengajar via online/jarak jauh.Pembelajaran online adalah pembelajaran yang dilakukan dengan menggunakan koneksi internet sebagai penghubung komunikasi antara pendidik dan siswa tanpa kontak fisik. Online Pembelajaran Jarak Jauh dapat memanfaatkan perangkat (gadget) dan laptop melalui beberapaportal dan aplikasi pembelajaran online. Proses pembelajaran online terdiri dari: pertama; Tatap muka virtual melalui konferensi video, telekonferensi, dan/ atau diskusi kelompok dimedia sosial atau aplikasi perpesanan.. media sosial adalah jalan keluar untuk menghilangkan kebosanan ataustres belajar di rumah. Sejalan dengan teori behavioristik, terjadi perubahan dalam perilaku mahasiswa dan dosen berdasarkan fenomena baru. Tingkah laku yang dapat dilihatdari hasil proses pembelajaran selama pandemi COVID-19. teori kognitif,yaitu perilaku individu dapat diarahkan melalui situasi baru, seperti belajar denganmodel online.

Proses ini berjalan pada skala yang belum pernah diukur dan diuji karena memilikitidak pernah terjadi sebelumnya. Tidak dapat dihindari bahwa desa-desa terpencil dengan populasi kecil adalahbingung, karena infrastruktur teknologi informasi sangat terbatas. Juga, saat belajar di kampus, dosen menyampaikan materi langsung di kelas, menjelaskan dimerinci materi dari awal hingga akhir, dan dapat langsung memantau level siswapemahaman materi yang disampaikan. Jadi penilaian internal untuk kampus adalah dianggap mendesak bagi keluarga mahasiswa. Informasi penilaian sangat penting. Beberapamenganggap hilangnya informasi penilaian siswa sangat berarti bagikeberlanjutan masa depan siswa. Misalnya, siswa yang telah mampu menguasaibanyak keterampilan tahun ini tetapi tidak menerima penilaian yang sesuai tahun ini, sehingga akanberdampak pada pengobatan untuk tahun mendatang. Lain halnya dengan mahasiswa di perguruan tinggi.Banyak perguruan tinggi di luar negeri telah menggantikan ujian tradisional dengan alat online. Inikondisi baru bagi dosen dan mahasiswa.

Oleh karena itu, peran dosen sangat dibutuhkan dalam mengelola atau mengelola pembelajaran yang dimulaimulai dari perencanaan, pengorganisasian, penggerakan dan evaluasi untuk meningkatkan efektivitas proses belajar mengajar di masa pandemi COVID-19 saat ini, baik dipelaksanaan pembelajaran jarak jauh dalam jaringan (online) dan di luar jaringan(luring). Oleh karena itu, dosen harus mampu menggunakan metode dan pendekatan serta menggunakansarana dan prasarana yang memadai sehingga proses belajar mengajar menjadi menarik dan menyenangkan. Memberikan ruang seluas-luasnya bagi siswa untuk berkreasi danterlibat secara aktif selama proses pembelajaran. Sampai kognitif, afektif dan ranah psikomotorik siswa dapat tumbuh dan berkembang secara optimal dan simultantanpa mengalami stunting. 


\section{Daftar Pustaka}

Arzayeva, M., Rakhimzhanov, K., Abdrahmanova, A., \& Umitkaliev, U. (2015). Special aspects of distance learning in educational system. Anthropologist, 22(3), 449-454. https:// doi.org/10.1080/09720073.2015.11891 900

Arizona, Kurniawan. et.all. (2020). Pembelajaran Online Berbasis Proyek Salah Satu Solusi Kegiatan Belajar Mengajar di Tengah Pandemi Covid-19. Jurnal Ilmiah Profesi Pendidikan. Volume 5 No 1 Mei 2020. (Online): https://jipp.unram.ac.id/index. php/jipp/article/download/111/99. DOI: 10.29303/jipp.v5i1.111

Jamaluddin, D., Ratnasih, T., Gunawan, H., \& Paujiah, E. (2020). Pembelajaran daring masa pandemik Covid-19 pada calon dosen: hambatan, solusi dan proyeksi. LP2M.

Kim, Y., Wang, Y., \& Oh, J. (2016). Digital Media Use and Social Engagement: How Social Media and Smartphone Use Influence Social Activities of College Students. Cyberpsychology, Behavior, and Social Networking. https://doi.org/10.1089/ cyber.2015.0408

Miles, M. B., \& Huberman, M. (1994). Qualitative Data Analysis Second Edition. SAGE Publications.
Naserly, M. K. (2020). Implementasi Zoom, Google Classroom, Dan Whatsapp Group Dalam Mendukung Pembelajaran Daring (Online) Pada Mata Kuliah Bahasa Inggris Lanjut (Studi Kasus Pada 2 Kelas Semester 2, Jurusan Administrasi Bisnis, Fakultas Ekonomi dan Bisnis, Universitas Bina Sa. Aksara Public, 4(2), 155-165.

Oknisih, N., \& Suyoto, S. (2019). Penggunaan Aplen (Aplikasi Online) Sebagai Upaya Kemandirian Belajar Siswa. In Seminar Nasional Pendidikan Dasar (Vol. 1, No. 01)

Silalahi, T. et al. (2020). The Application of Cooperative Learning Model during Online Learning in the Pandemic Period. Budapest International Research and Critics InstituteJournal (BIRCI-Journal). P. 1683-1691.

Sitorus, H.V., et al (2019). The Effect of Learning Strategy and Thinking Ability on the Students' Learning Outcomes in Economics Subject of XI Social Students in Senior High School State 1 in Pematang Siantar. Budapest International Research and Critics in Linguistics and Education (BirLE) Journal. P. 451-460.

Zahrotunni'mah. (2020). Langkah Taktis Pemerintah Daerah Dalam Pencegahan Penyebaran Virus Corona COVID-19 di Indonesia. Jurnal Sosial dan Budaya Syar'i Vol. 7 No. 3 (2020), pp.247-260, DOI: $10.15408 /$ sjsbs.v7i3.15103. 